\title{
Existence of Salafi Education Institutions in West Nusa Tenggara: Study on Resistance and Conflict of Beliefs and Student's Parents Motivation in Selecting the Salafi Educational Institutions
}

\author{
Hasbialloh \\ Islamic State University of Mataram, Indonesia \\ http://dx.doi.org/10.18415/ijmmu.v8i10.3060
}

\begin{abstract}
Generally, Salafi is religious group which is emphasize to the purification of Islamic teachings based the Qur'an and Al-Hadist (the traditions of the Prophet) as well as attend to follow the comprehension of scholars of al-Salaf al-Sāli's Islamic teaching (called the generation of comrade or shahâbat), tâbi'în (followers of comrade) and atbâ ' al-tâbi'în (followers of tâbi'în). This study is a qualitative descriptive. The researcher describes the phenomenon that occurs in current Salafi educational institutions include the conflicts of belief and its resistance. This study was conducted at Islamic Boarding School of Abu Hurairah Mataram, As-Sunnah in East Lombok and Imam Bukhari in Dompu regency. Observation, interviews, and documentation was used to collect the data. The result of this study found that; 1) The characteristics of Salafi educational institutions in West Nusa Tenggara were held in the form of Khalafi education system, namely conducted public schools in the Islamic boarding school environment by emphasizing the cultivation of the faith and comprehension of Salaf (aqidah and manhaj Salaf). 2) The source of conflict occurred between Salafi and the community of Sasak in Lombok is the difference of understanding to the religious practices. The resistance that occurs to Salafi educational institutions was called close resistance, so that no significant influence on it existence of the Salafi educational institutions and, 3) The motivations that encourage the students's parents to select the Salafi educational institutions including the teaching of Salaf faith, memorizing the Qur'an base on salafi dak'wa, and save environment for the students. And also Salafi educational institutions provide the Islamic curriculum, the credibility of the teaching staff as well as the boarding school system.
\end{abstract}

Keywords: The Salafi Dak'wa; Conflict; Resistance; Motivation

\section{Introduction}

Generally, Salafi is a religious group which is emphasized to the purification of Islamic $d a$ 'wa (conveying and inviting to the Islamic way of life) based on the Qur'an and Al-Hadist (the traditions of the Prophet) as well as attend to follow the comprehension of ancient Ulama (scholars) of al-Salaf al-Sāli's to the Islamic teaching (called the generation of shahâbat (comrade)), tâbi'în (followers of a Sahabat) and atbâ ' al-tâbi'în (followers of tâbi'în). The people of Sasak Lombok viewed that Salafi is a religious group and has different religious practices. In this diversity, the people of Lombok adhere to the religious practice which is oriented to the local culture of Sasak, called Sasak Islam local. This Sasak Islam local actualizes 
Islam by insertion of local tradition. In this case, The Salafi criticizes the religious and cultural practices that are actually carried out by the Sasak people in Lombok.

The idea of Salfi da'wa (conveying or inviting to th islamai way of life) to purify the Islamic religion was contradicting with the society of Sasak Islam local. In the early years of the presence of Salafis in Lombok, the society of Sasak against the Salafi $d a$ 'wa in several places strongly. The conflict rise because the difference of religious practice

However, these conflicts and resistance rise, but does not reduce the existence of Salafi da'wa in west Nusa Tenggara. Further, to grow their $d a$ 'wa, Salafis organizes a public school by combining nonformal and formal education. These ideas are shown by developing several Islamic educational institutions from Madrasah Ibtidaiyyah (elementary school) to the high school level (Madrsaha Aliyah) base on the salafi dak'wa. This strategy has a significant impact on it the development. Then, educational institutions initiated by Salafis have got good response from several communities, not only from rural communities but also from the urban middle class. In recent years it has become an alternative school in thousands of existing schools and madrasas in West Nusa Tenggara.

To see the development of Salafi da'wa in West Nusa Tenggara, the data in the table below shown Islamic boarding school or pesantren which organize and develop by Salafi.

Table1. Islamic boarding schools developed and built by Salafi in West Nusa Tenggara in recent year

\begin{tabular}{lllcc}
\hline No & \multicolumn{1}{c}{ Institutions } & Area & Year & $\begin{array}{c}\text { Total students } \\
\mathbf{2 0 1 9 / 2 0 2 0}\end{array}$ \\
\hline 1. & Ponpes Abu Hurairah Mataram & Mataram & 2002 & 2984 \\
2. & Ponpes As Sunnah Bagek Nyak & East Lombok & 2005 & 2194 \\
3. & Ponpes Anas Bin Malik & East Lombok & 2000 & 618 \\
4. & Ponpes Tahfidzul Qur'an dan Dirasat & East Lombok & 2005 & 272 \\
& IslamIbnu Abbas & & & \\
5. & Ponpes Ar Risalah Semparu & Central Lombok & 2016 & 163 \\
6. & Ponpes Minhajus Shahabah & North Lombok & 2008 & 256 \\
7. & Teladan Imam Syafi'i & North Lombok & 2014 & 80 \\
8. & Ponpes Muadz Bin Jabal & North Lombok & 2014 & 146 \\
9. & SD-IT Imam Syafi'i & West Sumbawa & 2013 & 229 \\
10. & SD-IT Darussunnah & Sumbawa & 2012 & 258 \\
11. & Ponpes Imam Syafi'i & Bima & 2008 & 640 \\
12. & Ponpes Imam Bukhari & Dompu & 2014 & 964 \\
\hline
\end{tabular}

The data in the table above shown the existence of Salafi $d a$ 'wa in the middle of Sasak society in Lombok island and West Nusa Tenggara province.

Therefore, based on the phenomenon and data as mention earlier, this study was conducted on the growth of Salafi educational institutions in West Nusa Tenggara, both in Lombok Island and Sumbawa related to the development of Salafi educational institutions, the existence and student's parents motivation of West Nusa Tenggara community to select the Salafi educational institutions in the middle of faith conflict and resistance.

\section{Methodology}

This study is qualitative descriptive. The researcher describes the phenomenon that occurs in current Salafi educational institutions include the conflicts of belief and its resistance. This study was conducted at the Islamic Boarding School of Abu Hurairah Mataram, As-Sunnah in East Lombok, and Imam Bukhari in 
Dompu regency. To collect the data researcher use observation, interviews, and documentation. Further, the data were analyzed simultaneously, by following steps namely; data reduction, data presentation, and concluding. Triangulation was used to make validation and credibility tests internally, then, the researcher made detailed, clear, systematic, and reliable reports and descriptions externally.

\section{Result and Discussion}

The growth of Salafi's da'wa in West Nusa Tenggara both in Lombok and Sumbawa Island, its history cannot be separated from the historical roots of Salafis in Indonesia. It is Because several pioneering personage of Salafi's $d a$ 'wa in Indonesia also took part in spreading Salafi's $d a$ 'wa in Lombok. They were Yazid Jawas, Abdul Hakim Bin Amir Abdat, Aunurrafiq Ghufron, Mubarak Bamuallim, Abdurrahman AtTamimi, and others. They were joined local salafi da'wa in Lombok such as Fauzi Athar, TGH Husni, Mukti Ali Abdul Karim, Mahsun Muhammad Sholeh and also supported by a Salafist personage of Yemeni from Ampenan (ones of the old city in Lombok island located in Mataram), namely Abdurrahman Bin Hizam.

Those pioneers who meet with preacher personage in Lombok make the Salafi dak'wa begin to grow in Lombok. Then, in the 2000s, each of these personages decided to widen Salafi's da'wa through education by building educational institutions called pesanteren (Islamic boarding schools).

Furthermore, a personage of Salafi in Lombok such as Fauzi Athar and Abdurrahman Hizam who founded the Al Hunafa Foundation along with two other founders, namely Khalid Bawazir and Umar Jubair. Through this foundation, Abdurrahman Hizam and Fauzi Athar began to develop and introduce Salafi's dak'wa to the community of Sasak Lombok, especially located in West Lombok, Mataram, and East Lombok

Then, in 2002 the Al Hunafa' foundation established a boarding school called Abu Hurairah Islamic boarding school of Mataram, this pesanteren is integrated into the government curriculum (from the Ministry of Religion) with the Islamic boarding school curriculum.

On the year of 2004, after meeting with one of the pioneers of salafi's; Yazid Jawas, Husni (local personage), and his family, Sofyan Bafin Zen and Mizan Qudsiah, established the As-Sunnah Islamic Boarding School in East Lombok. And it became one of the Islamic Boarding School of Salafi in East Lombok as well as becoming the strategy that used to develop Salafi's $d a$ 'wa.

Meanwhile, Mukti Ali in west Lombok, after completing his education at the Islamic University of Medina and joining the board of directors at the Islamic boarding school Abu Hurairah in Mataram, he built pesanteren to enlarge the Salafi dak'wa. This pesantren located in Kediri West Lombok, namely Abu Dzar Al Ghifari Islamic Boarding School. In other side, Mahsun Muhammad Sholeh after meeting with Yazid Jawas joined as a teacher at the Abu Hurairah Islamic Boarding School in Mataram.

From these personage, salafi's dak'wa in West Nusa Tenggara began to spread and continues to grow, and even salafi's $d a$ 'wa is not only concentrated in Lombok area but also eventually spread to the island of Sumbawa. In Sumbawa Island, one of the personage namely Fuad Bin Sef from Bima, met with Abdurrahman Hizam they discussed about salafi's dak'wa growth in Lombok Island. Based on it, Fuad Bin Sef was introduced to the salafi's dak'wa by Abdurrahman Hizam and he also was introduced to Salafi personage in Lombok such as Fauzi Athar and others. And then, Abdurrahman Hizam Fuad Bin Sef also introduced Fuad Bin Sef to Yazid Jawaz. By effort which is done by Fuad Bin Sef, the salafi's dak'wa network in the Bima and Dompu regions developed. Further, Fuad Bin Sef met with Faruk Jafar Hamude in Dompu to discuss the salafi's dak'wa and he (Faruk) interested in taking part to develop the salafi's dk'wa in Dompu. 
In addition, Abdurrahman Bin Hizam not only meet with Fuad Bin Sef in the Bima area but also built communication with Fadal Bafadal in Sumbawa City to discuss salafi's dak'wa, thus, Fadal Bafadal finally continued to develop salafi's dak'wa in the Sumbawa city and its surroundings.

Therefore, from these personages, Salafism developed in the island of Sumbawa. Then, after conducting Salafi's dak'wa in Bima and its surroundings intensively, Fuad Bin Sef established a pesantren Imam Syafi'I which is located in the City of Bima in 2008. In Sumbawa city, after the next 4 years, Fuad Bin Sef established Darussunnah Islamic boarding school located in Sumbawa city. And in another side, Faruk Hamude founded Imam Bukhari Islamic Boarding School in Dompu Regency.

The existence of Salafi's dak'wa in West Nusa Tenggara has shown based on the growth of Salafi education intuitions. The educational system that they develop bycombining the religion Ministry curriculum with the Islamic boarding school curriculum. And also, the educational institution that they organize began from a low level such as elementary until senior high school. This system is implemented at three famous Islamic boarding schools in West Nusa Tenggara namely, Abu Hurairah Islamic boarding school in Mataram, As-Sunnah in East Lombok, and Imam Bukhari Islamic boarding schools in Dompu.

\section{Abu Hurairah Islamic boarding school in Mataram}

Abu Hurairah Islamic boarding school in Mataram was categorized into famous and growth institution. The total students were 2984. It's separated into all level educational institution. See table 2 for more detail.

Table 2 The Education Institution developed by Abu Hurairah Islamic boarding school in Mataram 2020/2021

\begin{tabular}{llc}
\hline No & \multicolumn{1}{c}{ Educational level } & Total students \\
\hline $\mathbf{1}$ & Male Islamic Elementary School & 580 \\
$\mathbf{2}$ & Female Islamic Elementary School & 535 \\
$\mathbf{3}$ & Male Junior high school Scool & 514 \\
$\mathbf{4}$ & Female Junior high school Scool & 469 \\
$\mathbf{5}$ & MA Plus (Special Islamic Senior high School) & 362 \\
$\mathbf{6}$ & Male Islamic Senior High school & 72 \\
$\mathbf{7}$ & Female Islamic Senior High school & 384 \\
$\mathbf{8}$ & I'dad Muallimat $\quad$ Total & 69 \\
\hline
\end{tabular}

Abu Hurairah Islamic boarding school in Mataram implemented formal education system under rule of both Religion Ministry of Indonesian Republic and Education and Culture Ministry. The level and education system can be seen in table 3 below.

Table 3 Level and Educational system implemented by Abu Hurairah Islamic boarding school in Mataram under Religion Ministry and Education and Culture Ministry

\begin{tabular}{|c|c|c|}
\hline \multicolumn{2}{|c|}{ Formal Education } & Informal \\
\hline Basic Level & High Level & Education \\
\hline Male Islamic Elementary School & MA Plus (Special Islamic Senior high School) & I'dad \\
\hline Female Islamic Elementary School & Male Islamic Senior High School & Muallimat \\
\hline Male Islamic Junior High School & & (Islamic High \\
\hline Female Islamic Junior High School & & School) \\
\hline
\end{tabular}


Abu Hurairah Islamic Boarding School organizes informal education called I'dad Muallimat. It is a preparing program for Arabic language acquiring and religion basic teaching for female students who graduated from Senior high school. These graduations were prepared to be the constructor of a boarding school who has good ability in using Arabic language and has the capability for basic religious comprehension. This program was held for three years and the graduation got a certificate in the form of an Islamic boarding school certificate.

\section{As-Sunnah Islamic boarding school in East Lombok}

Under Foundation of As-Sunnah, Islamic Boarding School of Imam Muslim located in Bagek Nyake East Lombok organized both level junior high school and senior high school which called Islamic junior high school and Islamic senior high school by combining the national curriculum and Islamic Boarding school curriculum. And characteristic of pesanteren As-Sunnah is stressing to the Indonesia Islamic Boarding school curriculum.

Also, As-Sunnah Islamic Boarding categorized into famous and growth institution. The total students were 2107. It's separated into all level educational institution. See table 4 for more detail.

Table 4 The Education Institution developed by As-ssunah Islamic boarding school in East Lombok 2020/2021

\begin{tabular}{llc}
\hline No & \multicolumn{1}{c}{ Educational level } & Total students \\
\hline $\mathbf{1}$ & Kindergarten & 178 \\
$\mathbf{2}$ & Islamic Elementary School As-ssunah & 409 \\
$\mathbf{3}$ & Islamic Elementary School Khadijah & 376 \\
$\mathbf{4}$ & Islamic Junior High School As-Sunnah & 272 \\
$\mathbf{5}$ & Islamic Junior High School Khadijah & 356 \\
$\mathbf{6}$ & Islamic Senior High School As-sunnah & 502 \\
$\mathbf{7}$ & Ma'had Aliy $\quad$ Total & 14 \\
& & 2107 \\
\hline
\end{tabular}

Additionally, As-sunnah Islamic boarding school of east Lombok implemented formal education system under rule both Religion Ministry of Indonesian Republic and Education and Culture Ministry. The level and system can be seen in table 5 as follows.

Table 5 Level and Educational system implemented by As-ssunah Islamic boarding school in East Lombok under Religion Ministry and Education and Culture Ministry

\begin{tabular}{|c|c|c|}
\hline \multicolumn{2}{|c|}{ Formal Education } & \multirow{4}{*}{$\begin{array}{c}\text { Informal } \\
\text { Education } \\
\text { Ma'had Aliy } \\
\text { (High Islamic } \\
\text { Education) }\end{array}$} \\
\hline Basic Level & High Level & \\
\hline Kindergarten & $\begin{array}{l}\text { Islamic Senior High } \\
\text { School As-sunnah }\end{array}$ & \\
\hline \multicolumn{2}{|l|}{ Islamic Elementary School As-ssunah } & \\
\hline \multicolumn{2}{|l|}{ Islamic Elementary School Khadijah } & \\
\hline \multicolumn{2}{|l|}{ Islamic Junior High School As-Sunnah } & \\
\hline Islamic Junior High School Khadijah & & \\
\hline
\end{tabular}

As-Sunnah Islamic Boarding School also organizes informal education called Ma'had Aliy. It is preparing program for Arabic language acquiring and religion basic teaching for female students who graduated from Senior high school. These graduations were prepared to be constructor of boarding school who has good ability in using Arabic language and has capability for basic religion comprehension base on salfi's dak'wa. 


\section{Imam Bukhari Islamic boarding schools in Dompu}

Earlier in the year of 2013 As-sunnah foundation in Dompu build Islamic Education Institution based on Salafi way of life at Dompu Regency. They established education institution from low level education namely Kindergarten and called Islamic Kindergarten of Ibnu Hajar.

Islamic Boarding School of Imam Bukhari was categorized into middle level Islamic boarding school and the totals of students were 1.164 and it's separated into all level educational institution. For more detail see table 6 below.

Table 6 The Education Institution developed by Imam Bukhari Islamic boarding school of Dompu Regency 2020/2021

\begin{tabular}{lcc}
\hline No & Educational level & Total students \\
\hline $\mathbf{1}$ & Islamic Kindergarten & 200 \\
$\mathbf{2}$ & Islamic Elementary School Imam Bukhari & 549 \\
$\mathbf{3}$ & Islamic Junior High School Imam Bukhari & 415 \\
$\mathbf{4}$ & Islamic Senior High School Imam Bukhari & First year \\
& Total & 1.164 \\
\hline
\end{tabular}

Same with other Islamic boarding school, Imam Bukhari Islamic boarding school in Dompu Regency also implemented formal education system under both Religion Ministry of Indonesian Republic and Education and Culture Ministry. The level and system can be seen in table 7 as follows.

Table 7 Level and Educational system organize by Imam Bukhari Islamic boarding school of Dompu Regency 2020/2021 under Religion Ministry and Education and Culture Ministry

\begin{tabular}{llc}
\hline \multicolumn{1}{c}{ Formal Education } & \multicolumn{1}{c}{ High Level } & Informal \\
Education
\end{tabular}

Therefore, the characteristics of Salafi educational institutions in West Nusa Tenggara, both in islands of Lombok and Sumbawa were organizing by the Khalafi Islamic boarding system, which is the implemented public schools or formal school in it environment by emphasizing the cultivation of faith and teaching based of the Salafi dak'wa. Khalafi is a model of Islamic boarding school which is organize of public school or formal education in it environment.

\section{The Conflict of Believe, Resistance and Existence of Salafi's Education Institution}

The conflict that occurred between Salafi and Sasak communities in Lombok and other places is in the difference of understanding religious practices. If we see deeply in society lives, conflicts will arise because the basic essence of human creation has a difference. The diversity of life essentially becomes the factual basis that conflicts will arise and occur in social life. It is In line with Plummer (2013), who emphasized that the embryos of conflict emerge at every level of social life.

Further, based on a theoretical perspective, the conflict occurs in society as a social ecosystem that cannot be avoided. Moreover, the theory of conflict views that social change does not occur through a process of adjusting values, but it occurs as a result of conflicts itself, it also the conflict is embedded in this life closely and because the Human being has always struggled to face the conflict. The conflict theories which expressed by Ralf Dahrendrof (see Santoso, 2012) stated that conflict is a necessity in society, and even the conflict is seen as a contributor to creating a better social order.

Existence of Salafi Education Institutions in West Nusa Tenggara: Study on Resistance and Conflict of Beliefs and Student's Parents Motivation in Selecting the Salafi Educational Institutions 
Moreover, the resistance that occurs to Salafi educational institutions is called close resistance so that it does not have a strong influence on the existence of Salafi educational institutions. According to Scott (2000), closed resistance is usually characterized by issues between one person and another so that people have the same perception about a certain object and usually closed resistance is carried out clandestinely.

\section{Student's Parent's Motivation in Selecting Salafi Education Institution in the Midst of Conflict of Believe and Resistance}

Worries about the educational needs of their children's future made student's parents very selective to select the education institution. This condition is described in the theory of motivation as an encouragement, both caused by internal and external factors, to achieve certain goals to fulfill a need.

Abraham Maslow (in Hamner, W. Clay, and D. Organ, 2005) believed that individuals have constant encouragement. The hierarchical system of needs, which is developed by Maslow, is a pattern commonly used to classify human motives. The motivation and reasons selected by parents in choosing the right school for their children are certain differences from one parent to another. And this motivation is grouped into two parts, namely motivation that comes inside called internal motives and motives that come outside called external motives.

In addition, the motivation that encourages the student's parents to select the Salafi educational institutions for their children was based on the internal motivation of parents, namely; understanding of Salafi dak'wa, memorizing the Qur'an which is programmed by the Islamic boarding school as well as saves and good environment. Meanwhile, an external motivation of parents was based on their interested to the curriculum that implemented by pesanteren, the credibility of the teaching staff and the boarding school education system.

\section{Conclusion}

A characteristic of Salafi educational institutions in West Nusa Tenggara organized in the form of Khalafi Islamic boarding school. The formal education system is organized in the Islamic boarding school by combining curriculum under religion ministry and local curriculum namely Islamic boarding school curriculum. Teaching and learning are strongly stressed to embed the values of faith, especially in teaching to the faith and religious practice based on salfi's dak'wa.

The conflict that occurred between Salafi and Sasak communities in Lombok and other places is due to the difference in understanding religious practices. The conflict that happens among them is hoped for both parties to take the function from the conflict itself was to construct for better social order in the society. The diversity of religious practice and understanding between them is difficult to be avoided. The resistance that occurred on Salafi's educational institution was called; close resistance so that it does not have a strong influence on the existence of Salafi educational institutions in West Nusa Tenggara generally.

Further, the motivation that encourages parents to select the Salafi educational institutions for their children was based on the internal motivation of parents, namely understanding to Salafi dak'wa by stressing to the faith and the religious practice based on Salafi teaching and dak'wa, memorizing to the holy book of Qur'an which is programmed as well as save and good Islamic boarding school environment. Meanwhile, an external motivation of parents was based on their interested to the curriculum that implemented by pesantren and the credibility of the teaching staff as well as the educational system that implemented in the form of boarding school. 


\section{References}

'Adb Allāh Ibn 'Abd al-hamid al-Athari (2014). Al-Wajiz fi 'Aqidat al-Salaf al-Salih. cetakan Turki: Al Ghuroba' Addaarul atsariyah lit tarjamati wat thobaa'ati wan nasyri.

Ken Plummer, Martono, Sisworo (2013). Sosiology The Basic. Rajawali Pers. Jakarta.

Bernard Raho (2007). Teori Sosiologi Modern. Prestasi Pustaka Publisher. Jakarta.

William, Hendricks, Arif Santoso (2012). Bagaimana Mengelola Konflik;Petunjuk Praktis Untuk Manajemen Konflik Yang Praktis. Bumi aksara. Jakarta.

Scoot, James (2000). Senjatanya Orang-orang yang Kalah; Bentuk-Bentuk Resistensi Sehari-hari Kaum Tani. Yayasan Obor Indonesia. Jakarta.

Prihartanta, Widayat (2015). Teori-teori Motivasi. Jurnal Adabiya, Vol. 1 No. 83. Universitas Islam Negeri Ar-ranir.

Hamner, W. Clay and D. Organ, 2005. Organizational Behavior an cipscholoiroach. Business Publications. Dallas.

\section{Copyrights}

Copyright for this article is retained by the author(s), with first publication rights granted to the journal.

This is an open-access article distributed under the terms and conditions of the Creative Commons Attribution license (http://creativecommons.org/licenses/by/4.0/). 